\title{
Manipulation of Globalisation
}

\author{
Yongxiu Zhou \\ Department of Foreign Language Teaching and Research, Taishan University \\ Tai'an 271021, Shandong, China \\ E-mail: yongxiuzhou@sina.com
}

\begin{abstract}
Globalisation is a big but controversial issue: What are the major forces for globalisation? Will globalisation bring about more opportunities or more risks? Is globalisation an economic, technological, cultural, social or political issue? Different understanding of and different attitudes towards globalisation affect the process of globalisation differently. Meanwhile, the theories on globalisation are themselves a powerful weapon, which has been used to promote or fight against globalisation.
\end{abstract}

Keywords: Globalisation, Opportunities, Risks, Information age, White paper

\section{What's Globalisation?}

A multitude of scholars have so far studied and defined "globalisation" from different perspectives, but of the various definitions I prefer this one: "globalisation means the growing interdependence and interconnectedness of the modern world"(the Secretary of State for International Development, UK, 2000), because I believe that "globalisation is political, technological and cultural, as well as economic"(Giddens, 1999, in Mohan, 2000).

\section{Drives for Globalisation}

The British government has clearly summarised the driving forces for globalisation:

"The increased ease of movement of goods, services, capital, people and information across national boarders is rapidly creating a single global economy. The process is driven by technological advance and reduction in the cost of international transaction, ..." (White Paper: 15).

Among the aforementioned various forces, Mohan (2000:127) stressed that "the rapid increase in the volume of financial flow is, possibly, the defining feature of globalisation". In my opinion, it is largely the capitalist pursuit of maximising profits that drives globalisation forward. Some Western scholars may argue that "globalisation cannot be reduced to a question of capitalism alone" (Scholte, 1997, in Mohan: 121), but they also admit that "the pursuit of surplus accumulation has provided a principal and powerful spur to globalisation" (Scholte, 1997, in Mohan: 121). The profits created by globalisation don't always come from the traditionally defined international trade, as most people may have imagined. Statistics shows that "globalisation is characterised, too, by the growth of transnational companies, which now account for about a third of world output and two-thirds of world trade..." (White Paper: 15).

Thus, the global firm is regarded as the ideal-typical model of global production, because the global firms, with the ability to integrate production, marketing and consumption, are better equipped "to exploit the comparative advantages attendant upon each part of the process. If one part becomes uncompetitive it can be moved to another more competitive location. Such integration allows the parent company to retain the intellectual property rights" (Mohan: 125).

Obviously, this functional integration, which facilitates intra-firm trade, decides "profits, however, tend to go to the countries in the North where TNCs have their headquarters" (Rigg: 36). In a word, the economic force is a very powerful incentive to globalisation.

\section{The West and the East: Different Attitudes toward Globalisation}

Of all the factors that affect globalisation, I personally believe that the attitudes of national governments towards globalisation are crucial to the process of globalisation. If a government believes in the opportunities created by globalisation, it will endeavour to push globalisation forward. On the contrary, if a government believes in the risks created by globalisation, it will be either reluctant to align itself with globalisation or be resistant to globalisation. In this case, it is vitally necessary to discuss the different conceptions of globalisation held by different countries. 


\subsection{Opportunities}

It's universally agreed that "globalisation creates unprecedented new opportunities and risks", in the terms of Tony Blair (2000), but the Third World, on a whole, argues that the opportunities are exclusively for the rich countries while the risks are mainly for the poor ones.

In this respect, the British government claims that "it depends on the policy choices adopted by governments, international institutions, the private sector and the civil society" (White Paper: 15), because if "managed wisely, the new wealth being created by globalisation creates the opportunities to lift millions of the world's poorest people out of the poverty. Managed badly and it could lead to their further maginalisation and impoverishment"(White Paper: 15).

Then what are good policies? Aziz and Westcott (1997) argued that what matters is the complementarity of with three separate elements needed in combination: "trade openness, macro stability and a relatively low degree of government involvement in economic activity" (Mosley: 613). As a matter of fact, "good policy takes on a different meaning in each developing or transitional country contingent on its structure, its stage of development and the external shock to which it is subject. In particular, policy response varies by region" (Mosley: 614). The British government concluded that "openness is a necessary--- though not sufficient---condition for national prosperity" (White Paper: 17). It's true that, after the developing countries inserted themselves into the global market, they "have seen a substantial increase in their trade/GDP ratios" (Kaplinsky: 119), but ironically, at the same time, "its share of global output fell markedly (Kaplinsky: 119). This phenomenon was termed by Kaplinsky as "immiserising growth", describing "a situation where there is increasing economic activity (more output and more employment) but falling economic returns" (Kaplinsky: 120).

It's undeniable that "globalisation has seen a massive increase in global wealth" (Rigg, 2001). But the Third World countries are concerned with how the wealth created by the globalisation is distributed among countries, and whether the globalisation has increased the inequality between countries. Also ironically, drawing on the same facts, the rich countries and the poor ones have come to opposite conclusions.

The British government (2000) asserted that "the best evidence to date suggests that there's no systematic relationship between openness and inequality, or between growth and inequality"(White Paper: 15). One of their major evidences is that in 1990 the average real income in the countries containing the richest fifth of the world's population was 18 times greater than in the countries containing the poorest fifth; "by the late 1990s, this has fallen to 15 times greater"(White Paper: 15).

Meanwhile, Rigg (2001), based on the World Development Indicators (1999) released by the World Bank, argues while world GDP grew sharply, "there has been a widening gap between a wealthy elite of countries and a mess of poor countries" (Rigg: 36). "At the same time as the world has become richer, the number of people living in poverty has increased - to around 1.2 billion on the basis of the World's Bank's definition, which is those living on US\$1 a day or less" (Rigg: 37). Even a WTO-sponsored report published in 2000 acknowledged the fact: "While there is no simple relationship between trade and poverty, the evidence seems to indicate that trade liberalisation is generally a positive contribution to poverty alleviation..."(Rigg:37). This seems strikingly contrary to the British government's belief: "economic growth is an indispensable requirement for poverty reduction" (White Paper: 18).

It is the writer's view that the aforesaid discovery by the poor countries has, in fact though not expressed, caused them to suspect that the West seems to have been trying to mask the truth, and more terribly, this will cause the Third World to suspect whatever conclusions the First World will draw, at least in terms of globalisation. The different understanding of globalisation is not only caused by different international political ideologies, but also caused by different methodologies. For example, employing different statistical and analytic methods, we may come to different conclusions about the same phenomenon. Therefore, to label the issue as "ideological" couldn't put an end to the debate.

For instance, in terms of the different results of globalisation achieved by the rich countries and the poor ones, the Western powers declared this depends on "initial circumstances and on the policies that government pursue"(White Paper: 35). But the reality is that the initial economic and technological circumstances in the poor countries are absolutely inferior to those in the rich countries, which means that most of (if not all) the poor countries are doomed to impoverishment and marginalisation, even after they have turned to the global economy at immense costs. Confronted with this reality, the British government claims "all profound economic and social change produces winners and losers"(White Paper: 18). And a WTO-sponsored report echoed: "However trade reforms will create some losers (some even in the long run...)" (Rigg: 37). 


\subsection{Risks}

Nobody could deny that globalisation will create some unprecedented risks and challenges, as Tony Blair (1995) admits: "What is called globalisation is changing the nature of the nation-state as power becomes more diffuse and borders more porous. Technological change is already reducing the power and capacity of government to control its domestic economy free from external influence." (Mohan: 121)

But for the poor countries, the risks are even devastating sometimes, which the rich countries don't seem to bother to take into further consideration. Anyway, I will try my best to summarise the major risks sensed by the poor countries as follows:

Politically Globalisation requires a fundamental transformation of governments. It needs a more integrated approach to policy-making, "effective system of government and action against corruption. The government should ensure respect for human rights, and to promote security, safety and justice fro all"(White Paper: 19). The governments must react effectively to the fast changing world. While the public have easier access to information and power diffuses, the governments "have lost some control through globalisation process"(Mohan: 128 ) and will encounter more unpredictable challenges.

Economically The government must reduce their involvement in the market. The speeded up financial and informational flow requires more effective regulation of capital market. The government must make every effort to avoid "financial volatility", fight against indebtedness on a world scale, handle the more fierce competition within and between countries. The Third World must implement the Structural Adjustment Programmes (SAPs) to fit in the global economy, although the anti-globalists "believe that the type of development promoted by the World Bank and others lead to vulnerability and dependence" (Rigg: 36).

In fact, it's a hard nut for the Third World governments to maintain their economic growth and increased real income but in the meantime avoid economic dependence in the globalisation process.

Culturally Globalisation "is also reflected in the diffusion of global norms and values, the spread of democracy and proliferation of global agreements and treaties"(White Paper: 15). All these have raised the awareness of multiculturalism. Some people even go so far to call for a fight against cultural dominance or cultural imperialism.

Socially The poor countries have observed that globalisation has increased inequality within and between countries, which incites social conflicts. Meanwhile, fragmentation of ideologies is believed to be endangering the national unity and social security in some countries. More importantly, just as the G8 put it: "Globalisation has been accompanied by a dramatic increase in transnational organised crime.... Such crimes pose a threat not only to our citizens and their communities..., but also a global threat..." (Morrison: 72).

Ecologically Pursuing maximised profit has degraded our environment and threatened the ecological balance. But in reality, a world commitment to sustainable development is, for the most part, dependent on the guarantee of development for the poor.

\section{Globalisation in Information Age}

In order to analyse globalisation, many people have put forward various notions or frameworks such as "space-time distanciation" (Giddens, 1999), "time-space compression" (David Harvey, 1989), "widening" process and "deepening" process (Ankie Hoogvelt, 1997), etc. All of them provided new and useful insights into the process of globalisation, but all failed to account for the structure and sources of global powers.

In terms of international political economy, politics is "about the contestant over and contribution of resources" (Mohan: 123), but what are resources? Leftwich (1996) believes that resources are "both material and ideal" (Mohan: 123). These ideas, I strongly believe, could help expand our attention to both economic and non-economic dimensions of globalisation.

In 1994, Susan Strange created a new framework which

poists two forms of power: relational and structural. The former corresponds to the

Realist notion of differential state power such that country A can make country B do something they would not ordinarily do. This form of power is increasingly being replaced by structural power which is 'the power to shape and determine the structure of the global political economy within which other states, their political institutions, their enterprises and (not least) their scientists and other professional people have to 
operate" (Mohan: 123).

Strange further "disaggregates structural power into four intersecting facets which authority deprived. These four sources of power are the control over production, control over finance, control over market and control over information" (Mohan: 123).

Starting from this perspective, globalisation can be understood, to some extent, to be the process for capitalist core countries to establish, diffuse and consolidate their control over the periphery countries. This control is, to some people, linked to imperialism or neo-colonisation.

In our information age, the symbolic forms of products and commodities outweigh their material forms. Even in financial market, money doesn't take their material form as in the past: As stock market and currency market develop, money has "become a commodity in its own right" (Mohan: 127). In case of a film, what's embodied in its material form is vital to the producer, in the long run. Overwhelming popularity of some films creates sharper demand of more of its kind and even dominance of the market.

The latter instance has been associated by some with cultural imperialism. For some people, culture, economy and politics are intertwined in the cultural product, as is illustrated by Petras (1993): "United States cultural imperialism has two major goals: one economic and the other political; to capture markets for its cultural commodities and to establish hegemony by shaping popular consciousness" (Golding and Harris: 6). Later in 1995, Walters also concluded that "material and power exchanges in the economic and political arenas are progressively becoming displaced by symbolic ones, that is by relationships based on values, preferences and tastes rather by material inequality and constraint" (Golding and Harris:8).

In this case, the developing countries will readily accept the notion that "imperialism didn't maintain its rule merely through suppression, but through the export and institutionalisation of European ways of life, organisational structures, values and interpersonal relations, language and cultural products that often remained and continued to have impact even once the imperialists had gone home." (Sreberny-Mohammudi, in Golding and Harris: 51)

Although this idea is criticised by some, especially those from the West, it is, in my opinion, largely true in our age of corporate capitalism if we really take into account the experiences and feelings of the people in the poorer countries. And this can be partially justified by the fact that today globalisation of media has been given a very high priority in many countries, as I have observed.

As a matter of fact, the theory or concept about globalisation is itself an important factor, which has been significantly affecting the process of globalisation.

\section{My Attitude}

I personally believe that globalisation is an irreversible trend, and that no individuals, organisations or countries are likely to win the fight against it. In this case, it doesn't seem so important to argue whether opportunities or risks globalisation will bring about as to make every effort to predict the possible opportunities and risks in order to maximise the opportunities and minimise the risks. Furthermore, the opportunities and risks depend on the stages of development. In the short run, for most of the developing countries there will be more risks than opportunities, but in the long run, the opportunities will outweigh the risks.

In fact, the Third World has no choice but to align themselves with the global market. But, from the standing point of the developing countries, it is not advisable to open the markets as expected or instructed by the global economic powers, because this kind of obedience will cause serious risks or even damages to the developing countries. We, the Third World countries, should open ourselves tactfully, cautiously but firmly. In a word, my attitude toward - also my proposal about — globalisation is "restrictively welcome".

As for the adjustment or transformation within the developing countries, so far I have observed that some developing countries, such as China, are reluctant to adjust their political structure although they have started some economic reforms. According to classical Marxism, the political structure is based on or decided by the relevant economic structure, so once the economic base has been thoroughly transformed, the political structure will be restructured sooner or later. But this involves the modes of transformation. The former USSR's mode is that the political reform came before the economic reform, while the Chinese mode is the contrary. Which mode is better? Time will test it!

\section{References}

Blair, T. (2000). Foreword. White Paper on International Development.

During, S. (ed) (1993). The Cultural Studies Reader. London: Routledge. 
Golding, P. and Harris, P. (1999). Beyond Cultural Imperialism. Sage Publications.

Inglis, F. (1990). Media Theory. Oxford UK \& Cambridge USA: Blackwell.

Kaplinsky, R. (2000). Globalisation and Unequalisation: What Can Be Learned from Value Chain Analysis? The Journal of Development Studies, 37(2).

Kishan Thussu, D. (2000). International Communication. London: Arnold.

Lawrence \& Wishart (eds). (1998). Karl Marx \& Frederick Engels: Cellected Works, Vol. 35 and Vol. 37.

Mohan, G. (2000). Dislocating Power, Politics and Global Change. Geography, April.

Morris, J. (2001). Refugees---'The dark-side of globalisation': the criminalisation of refugees. Race and Class, 43(1).

Mosley, P. (2000). Globalisation, Economic Policy and Convergence. The World Economy, 23(5).

Rigg, J. (2001). Is globalisation good? Geography Review, 14(4).

Stevenson, N. (1999). The Transformation of the Media. London and New York: Longman.

The Secretary of State for International Development, UK. (2000). Eliminating World Poverty: Making Globalisation Work for the Poor--- White Paper on International Development. December (In this essay I refer to this document as "White Paper".).

Voices 21. (2000). A Global Movement for people's Voices in Media and Communication in the 21 century, in Maboy, M. (ed) Global Media Policy in the New Millennium. University of Luton Press.

W. Mcchesney, R. (2000). The Global Restructuring of Media Ownership, in Raboy, M. (ed) Global Media Policy in the New Millennium. University of Luton Press. 